\title{
Rabaska
}

Revue d'ethnologie de l'Amérique française

\section{FUMOLEAU, RENÉ. Légendes loucheuses. Racontées en français par PAUL VOUDRACK en 1955, et écrites par RENÉ FUMOLEAU, [Yellowknife], Les Éditions franco-ténoises, [2004], iv-41 p. Carte. ISBN 2-9808457-0-1}

\section{Faith Williams}

Volume 3, 2005

URI : https://id.erudit.org/iderudit/201724ar

DOI : https://doi.org/10.7202/201724ar

Aller au sommaire du numéro

Éditeur(s)

Société québécoise d'ethnologie

ISSN

1703-7433 (imprimé)

1916-7350 (numérique)

Découvrir la revue

Citer ce compte rendu

Williams, F. (2005). Compte rendu de [FUMOLEAU, RENÉ. Légendes loucheuses. Racontées en français par PAUL VOUDRACK en 1955, et écrites par RENÉ

FUMOLEAU, [Yellowknife], Les Éditions franco-ténoises, [2004], iv-41 p. Carte. ISBN 2-9808457-0-1]. Rabaska, 3, 147-147. https://doi.org/10.7202/201724ar d'utilisation que vous pouvez consulter en ligne. 
Fumoleau, RenÉ. Légendes loucheuses. Racontées en français par PaUL VOUDRACK en 1955, et écrites par RENÉ FumOLEAU, [Yellowknife], Les Éditions franco-ténoises, [2004], iv-41 p. Carte. ISBN 2-9808457-0-1.

Ce petit recueil rapporte des légendes du peuple Gwich'in de Red River, naguère appelé Loucheux, et vivant dans les Territoires du Nord-Ouest, près d'Inuvik. René Fumoleau se fait la plume de Paul Voudrack en transcrivant les six légendes que ce dernier lui avait racontées en français cinquante ans plus tôt. En préface, Alphonsine McNeely, la fille du conteur, brosse la biographie de son père, un Dènè d'origine gwich'in né à Arctic Red River (Tsiigehtchic), mais établi à Fort Good Hope. C'est là que, peu de temps après son arrivée dans le Grand Nord en 1953, René Fumoleau, un prêtre oblat d'origine française, s'intéresse aux traditions orales de ce peuple et recueille les récits de Paul Voudrack en 1955.

L'ouvrage contient deux récits mythiques, un récit étiologique et trois légendes. Les deux premiers récits sont des mythes. « Le Déluge » raconte l'origine du monde et «La Mauvaise Bête de l'eau : tuidetta » évoque une bête naufrageuse qui contrôle les eaux de la rivière Rouge. Le récit étiologique, " La légende d'Askidjek », occupe la majeure partie du recueil et elle se divise en dix-neuf sections dans lesquelles on livre diverses explications: pourquoi les animaux sont farouches, d'où viennent les maringouins et comment furent créées les montagnes. Askidjek, l'explorateur mythique de ce conte, se promène à pied et en canot dans les régions visitées, ce qui a pour effet de façonner le monde comme on le voit aujourd'hui. On trouve aussi trois légendes du cycle du corbeau rusé qui trompe l'ours noir, l'ours gris et l'homme : dans " Le Corbeau et l'ours noir ", la ruse du corbeau provoque la mort de l'ours ; «Le Corbeau et l'ours gris » explique pourquoi le renard marche.un peu de travers depuis que ses pattes, volées par l'ours gris, n'ont pas été remises à la bonne place par le corbeau; enfin, dans «Le Corbeau et la baleine et l'homme ", le corbeau vole la nourriture de l'homme pendant son sommeil. Ce répertoire de légendes, malgré sa brièveté, est une publication utile pour connaître la littérature orale des Amérindiens de l'Ouest canadien qui s'exprimaient naguère en français.

Faith Williams

Université Sainte-Anne, Pointe-de-l’Église 